\title{
Peningkatan Resiliensi Ekonomi Masyarakat Berdasarkan Tingkat Kerugian Ekonomi di Kawasan Terdampak Kali Lamong Kabupaten Gresik
}

\author{
Amalia Madina dan Eko Budi Santoso \\ Departemen Perencanaan Wilayah dan Kota, Fakultas Arsitektur, Desain, dan Perencanaan \\ Institut Teknologi Sepuluh Nopember \\ e-mail: eko_budis@urplan.its.ac.id
}

\begin{abstract}
Abstrak - Kabupaten Gresik merupakan salah satu daerah terdampak banjir kiriman dari Kali Lamong tahunan. Desa Deliksumber, Kecamatan Benjeng adalah desa yang bersiko tinggi terdampak banjir. Banjir ini rentan merugikan kegiatan ekonomi masyarakat, khususnya pertanian. Sehingga untuk mengatasi permasalahan tesebut diperlukan upaya peningkatan resiliensi ekonomi masyarakat berdasarkan kerugian yang diterima. Penelitian ini bertujuan untuk memahami upaya yang diperlukan masyarakat untuk meningkatkan resiliensinya ketika terdampak banjir. Penelitian ini menggunakan pendekatan kuantitatif dengan instrument kuesioner melalui metode Damage and Loss Assessment (DaLA) untuk mengetahui angka kerugian ekonomi masyarakat dan Content Analysis untuk merumuskan usulan bantuan bedasarkan masyarakat ketika banjir. Dari hasil penelitian petani mengalami kerugian tanaman dan peningkatan ongkos produksi, dengan kerugian ekonomi total sebesar Rp 155.235.600. Upaya yang perlu diperhatikan berdasarkan pendapat masyarakat ialah pemberian bantuan bibit, pupuk,dan alat pertanian, mengaktifkan dapur umum dan bantuan sembako, serta pembuatan tanggul dan normalisasi sungai Kali Lamong
\end{abstract}

Kata Kunci-Kerugian Ekonomi Masyarakat, Resiliensi Banjir, Damage and loass assesment, Content analysis

\section{PENDAHULUAN}

$\mathrm{B}$ ENCANA banjir adalah salah satu jenis bencana alam hidrometeorologis yang pada umumnya disebabkan oleh curah hujan yang tinggi di atas normal sehingga sistem pengaliran air yang terdiri dari sungai dan anak sungai alamiah serta sistem drainase dangkal penampung banjir buatan yang ada tidak mampu menampung akumulasi air hujan tersebut sehingga meluap [1].

Banjir menyebabkan kerugian yang luar biasa dan mengakibatkan penderitaan yang tak terhitung dibandingkan bencana alam lainnya didunia. Bahkan saat ini, banjir menyebabkan dampak dan kerugian ekonomi bagi masyarakat dengan angka kerugian yang tengah meningkat pada tingkat yang mengkhawatirkan [2]. . Dampak yang dialami oleh daerah perkotaan dimana didominasi oleh permukiman penduduk juga berbeda dengan dampak yang dialami daerah perdesaan yang didominasi oleh areal pertanian [13]. Dampak banjir yang terhadap ekonomi masyarakat dapat dikaji melalui tiga variabel yakni apakah mata pencaharian, kepemilikan barang berharga, dan pendapatan yang dimiliki masyarakat sebagai modal untuk hidup menghilang atau berkurang ketika terdampak banjir [14]
Fenomena ini menciptakan suatu kebutuhan untuk menjaga resiliensi ekonomi masyarakat terdampak bencana melalui manajemen resiko bencana. Resiliensi merupakan kemampuan sebuah sistem, komunitas atau masyarakat yang terdampak oleh bencana untuk melawan, menyerap, mengakomodasi dan memulihkan diri dari dampak suatu bahaya secara cepat dan efisien, termasuk melestarikan dan memulihkan struktur dan fungsi dasar yang penting sebagai upaya manajemen Resiko bencana [3]. Sehingga resiliensi ekonomi mengacu pada tanggapan inheren dan adaptif terhadap bencana yang memungkinkan masyarakat untuk mengurangi atau menghindari kerugian [4] Konsep ini dianggap lebih efektif dan memiliki prespektif jangka panjang sehingga dapat menciptakan pembangunan yang berkelajutan. Sehingga, prinsip pengurangan Resiko bencana saat ini, lebih ditekankan pada upaya peningkatan terhadap resiliensi bencana, baik di tingkat individu, komunitas, dan secara global.

Bencana bajir sering terjadi di Daerah Aliran Sungai (DAS) Kali Lamong mengalir melalui Kabupaten Gresik, Kabupaten Lamongan, Mojokerto, dan Kota Surabaya. RTRW Kabupaten Gresik 2010-2030 menyatakan bahwa kawasan rawan bencana banjir Kabupaten Gresik berada di Kecamatan Balongpanggang, Kecamatan Benjeng, Kecamatan Kedamean, Kecamatan Menganti, dan Kecamatan Cerme. Bencana banjir yang dialami dapat digolongkan dalam jenis mekanisme terjadinya adalah regular flood, dimana juga merupakan banjir kiriman dari bagian hulu Sungai Kali Lamong dan merupakan jenis banjir sungai pula. [6][12]. Keadaan Kali Lamong saat ini sudah tidak mampu lagi menampung debit air yang setiap tahun semakin bertambah volumenya. DAS Kali Lamong hanya memiliki kapasitas debit air sebesar 250 -270 $\mathrm{m}^{3} /$ detik sedangkan berdasarkan data statistik daerah rata-rata tahunan, debit air yang masuk meningkat hingga $400 \mathrm{~m}^{3} / \mathrm{dtk}$. Kondisi ini menyebabkan timbulnya bencana banjir tahunan di saat musim hujan. Bencana Dari berbagai daerah rawan banjir tersebut, terdapat beberapa desa terdampak yang turut menjadi langganan banjir, yaitu Desa Deliksumber di Kecamatan Benjeng.

Berdasarkan Data Desa atau Kelurahan Rawan Bencana Tahun 2017 Kabupaten Gresik, Desa Deliksumber termasuk wilayah dengan Resiko bahaya banjir yang tinggi. Sektor pertanian, paling banyak terdampak banjir dimana mata pencaharian penduduk terbesar adalah petani. Tercatat kerugian yang menimpa masyarakat selama tahun 2015 di Desa Deliksumber adalah terendam banjir dengan ketinggian 
air maksimal mencapai $30 \mathrm{~cm}$. Kondisi ini menyebabkan terendamnya 300 rumah warga dan 900 warga menjadi terganggu aktivitas sehari-harinya. Dalam bidang perekonomian, banjir telah menyebabkan kerugian berupa terendamnya sawah seluas 117 ha di Desa Deliksumber [5].

Berdasarkan ungkapan data banjir BPBD di tahun 2016 di Desa Deliksumber banjir merendam 200 rumah warga dan 115 Ha sawah, dengan ketinggian genangan mencapai $70 \mathrm{~cm}$. Sedangkan pada tahun 2017 banjir merendam 228 rumah dan 117 Ha sawah dengan ketinggian rata-rata sama. Dapat diketahui bahwa kondisi di Desa Deliksumber semakin memburuk dengan jumlah lahan sawah terendam meningkat. Kondisi ini menyebabkan warga petani kehilangan pendapatannya dan kerugian lainnya seperti biaya bibit pemupukan dan bajak sawah karena terjadi gagal panen akibat bencana banjir. Lahan pertanian yang mengalami penggenangan oleh air banjir tidak bisa ditanami oleh para petani. Jalan yang terendam air akibat banjir akan mempersulit aksesbilitas masyarakat untuk melakukan aktivitas dalam pemenuhan kebutuhan hidup.

Pemerintah pada dasarnya, telah memberikan bantuan berupa bibit maupun pupuk bagi para petani. Namun dengan bantuan tersebut kerugian yang dialami masyarakat masih belum tergantikan dimana berdasarkan teori yang telah disampaikan sebelumnya dapat dipahami bahwa memberikan bantuan untuk menanggulangi kerugian ekonomi masyarakat tidak cukup dengan kata lain kurang tepat. Akibatnya, kerugian ekonomi yang dialami masyarakat tidak dapat dipulihkan begitu saja dengan bantuan tersebut, selain itu masyarakat tidak dapat memiliki kemampuan resiliensi yang kuat karena tidak dapat beradaptasi dari keadaan yang menimpanya.

Sehingga melihat dari permasalahan Desa Deliksumber yakni perihal kerugian ekonomi yang dialami oleh masyarakat maka dimensi yang akan dibahas dalam penelitian ini ialah ekonomi masyarakat, karena banyak terjadinya kerugian yang dialami masyarakat akibat banjir dari segi ekonomi. Selain itu kegiatan ekonomi penduduk yang paling rentang terhadap terhadap banjir adalah pertanian, dimana pada Desa Deliksumber mempunyai prosentase penggunaan lahan bagi lahan pertanian cukup besar dibandingkan desa lainnya di Kabupaten Gresik. Pengukuran resiliensi ekonomi masyarakat berdasarkan angka kerugian ekonomi kegiatan pertanian digunakan pula usulan upaya dari masyarakat sebagai masukan untuk mengetahui upaya yang sesuai atau tepat untuk diterapkan di Desa Deliksumber agar dapat mengurangi kerugian yang dialami masyarakat. Sehingga perlu diketahui dan dipahami bagaimanakah angka kerugian ekonomi masyarakat desa untuk mengetahui resilensi masyarakat sebagai upaya menanggulangi kerugian bencana banjir di Desa Deliksumber?.

\section{METODE PENELITIAN}

\section{A. Jenis dan Pendekatan Penelitian}

Pendekatan yang digunakan dalam penelitian ini adalah pendekatan rasionalistik. Jenis penelitian dalam penelitian ini adalah deskripti kuantitatif dan kualitatif

\section{B. Variabel Penelitian}

Variabel penelitian yang digunakan untuk mengidentifikasi angka kerugian ekonomi masyarakat adalah penelaian kerusakan dan kerugian berdasarkan variabel kerusakan dan kerugian perumahan dan pertanian. Kerusakan dan Kerugian pertanian meliputi kerusakan tanaman atau lahan, sarana irigasi, mesin dan bangunan, dan biaya produksi

\section{Mengidentifikasi Angka Kerugian Ekonomi Masyarakat}

Metode Damage and Loss Assessment (DaLA) digunakan untuk mengidentifikasi angka kerugian ekonomi masyarakat akibat bencana banjir di Desa Deliksumber. Metode ini menggunakan bantuan kuesioner dengan tahapan-tahapan dalam metode ialah : [6]

a. Penilaian Kerusakan

Nilai kerusakan diperoleh dengan mengkalikan data jumlah unit fisik yang rusak dengan harga satuan yang diperoleh saat pengumpulan data primer. Pada penilitian ini kerusakan yang dinilai ialah berkaitan dengan indikator kepemilikan aset. Berikut rumus untuk penilian kerugian.

Tingkat kerusakan terdiri dari kategori rusak berat, sedang, dan ringan. Masing-masing kategori mempunyai kriteria sendiri dengan harga satuan berbeda menurut tingkat kerusakannya.

b. Penilaian Kerugian

Penilaian kerugian adalah penilaian yang berkaitan dengan nilai kerugian atau kehilangan pendapatan yang dialami oleh masyarakat akibat terganggunya alur pekerjaan, aset dan kegiatan ekonomi yang dimiliki. Nilai kerugian berhubungan dengan indikator pendapatan, pekerjaan, kepemilikan aset, keuangan dan tabungan yang dipunyai oleh masyarakat.

Tahapan tersebut nantinya akan ditabulasikan dengan analisa deskriptif kuantitatif. Sehingga, nantinya akan dapat menjadi masukkan untuk tahapan analisa selanjutnya..

\section{Merumuskan Usulan Upaya yang Harus dilakukan} Berdasarkan Masyarakat

Metode content analysis adalah suatu teknik untuk membuat inferensi-inferensi yang dapat ditiru (replicable) dan sahih, dengan memperhatikan konteksnya. Adapun tahapan dalam melakukan content analysis adalah sebagai berikut.

1. Unitizing (Pengunitan) : Menentukan unit oservasi dan unit analisis

2. Sampling (Penyamplingan) Membatasi observasi yang merangkum semua jenis unit yang ada.

3. Coding (Pengodean) merupakan tahapan menandai informasi-informasi dalam data teks

4. Reducing (Penyerdehanaan) Penyederhanaan dilakukan dengan teknik assertion analysis, dimana dapat memperlihatkan frekuensi dari beberapa objek tertentu yang dicirikan dengan cara tertentu

5. Infering (Pemahaman) Pemahaman terhadap data diperlukan untuk menarasikan arahan untuk selanjutnya disimpulkan.

6. Narrating (Menarasikan) Merupakan hasil penarasian dari tahap sebelumnya yang mampu menjawab pertanyaan penelitian

Analisa ini dilakukan melalui wawancara In-depth Interview berdasarkan hasil penelitian mengenai kerugian ekonomi masyarakat.Setelah analisa berakhir maka akan dapat dipahami usulan arahan adaptasi yang diperlukan berdasarkan masyarakat. 


\section{HASIL DAN DISKUSI}

A. Mengidentifikasi Angka Kerugian Ekonomi
Masyarakat
Pada tahun 2017 tercatat bahwa banjir di Desa
Deliksumber telah merendam $117 \mathrm{Ha}$ lahan pertanian dari 150,75 Ha yang digunakan sebagai lahan pertanian. Desa Deliksumber mempunyai dua jenis komoditas tanaman yang diterapkan yakni padi dan jagung. Dimana kedua komoditas ini memiliki tiga kali masa tanam (MT). MT I dilakukan pada bulan Januari hingga April dengan menanam komoditas padi berjenis ciherang. MT II dilaksanakan pada bulan Juni hingga Agustus dengan menanam komoditas Jagung. MT III dilakukan pada bulan September hingga Desember. Perbedaan komoditas yang ditanam pada setiap masa tanam ini dipengaruhi oleh ketersediaan air bagi lahan pertanian di Desa Deliksumber, dikarenakan jenis lahan pertaniannya ialah pertanian tadah hujan. Lahan pertanian di Desa ini tidak memiliki saluran irigasi desa khusus yang digunakan untuk mengaliri lahan. Kondisi ini mengharuskan petani mengganti komoditas di MT II karena dalam jangka waktu tersebut adalah musim kemarau dimana ketersediaan air menipis, sehingga perlu diganti dengan komoditas jagung atau palawija yang tidak membutuhkan sumber daya air yang banyak seperti padi.

Berdasarkan identifikasi kerusakan dan kerugian yang dialami masyarakat petani, diketahui bahwa petani di Desa Deliksumber pada tahun 2017 tidak mengalami kerugian dalam rumah tinggal, sarana irigasi, dan serta mesin dan bangunan. Berdasarkan laporan dari BPBD Kabupaten Gresik, banjir yang melanda Desa Deliksumber tidak mengakibat kerusakan yang berarti pada rumah tinggal petani, sedangkan di Desa Deliksumber tidak memiliki jaringan irigasi desa secara khusus yang dimanfaatkan untuk kegiatan pertanian. Kerugian pada mesin dan bangunan kegiatan petani juga masih bisa dihindari dengan memindahkan barang-barang tersebut ketempat yang aman dari banjir.

Kerugian yang dialami petani adalah kerusakan bibit dan tanaman namun tidak untuk kerusakan lahan pertanian karena setelah air banjir surut lahan pertanian dapat berfungsi kembali. Menurut data Dinas Pertanian Kabupapten Gresik pada tahun 2017, Desa Deliksumber mengalami kerusakan bibit dan tanaman dengan jenis Ciherang seluas $107 \mathrm{Ha}$, lebih jelasnya dapat dilihat pada gambar 1 .

Harga panen/Kg dari gabah padi yang dijual menurun $21 \%$ dimana harga gabah pada umumnya mencapai Rp 4.800 / Kg. Penurunan harga ini diakibatkan oleh kualitas gabah yang menurun, meskipun total jumlah produksi dapat dikatakan tidak banyak berkurang beratnya saat banjir. Hal tersebut terjadi ketika gabah menjadi hitam dan tidak berisi gabah melainkan air, serta banyak terkandung lumpur akibat terendam banjir dalam kurun waktu yang cukup lama. Karena banjir umur padi yang menjadi pendek karena harus dipanen agar tidak gagal panen karena terendam air dalam waktu yang lama lagi. Sehingga produktivitas padi pada tahun 2017 masih bisa dipertahankan nilainya yakni 6,56 Ton/Ha untuk Desa Deliksumber.

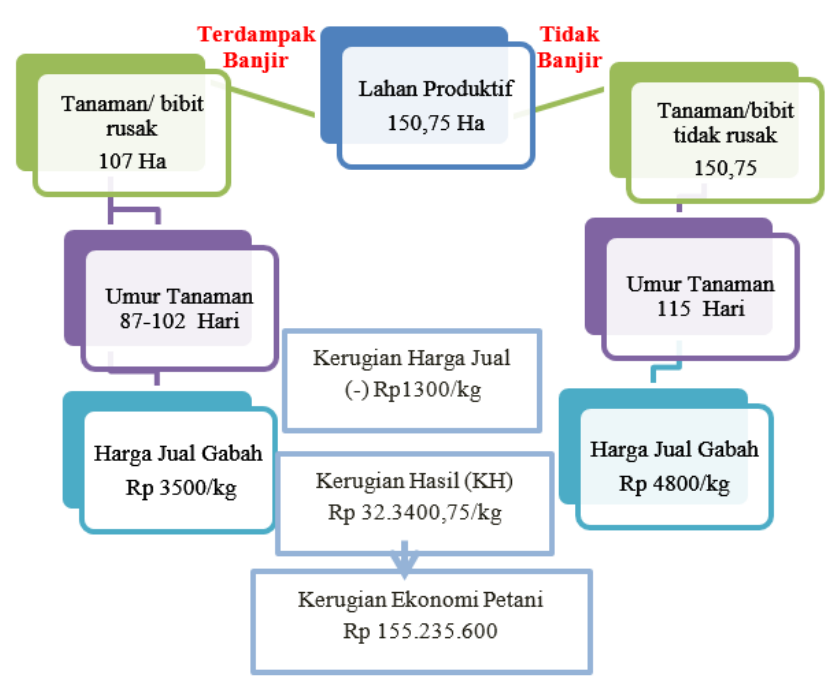

Gambar 1. Grafik Kerugian Ekonomi Pertanian

Pada tahun 2017, secara keseluruhan berdasarkan perhitungan kerugian hasil $(\mathrm{KH})$ dan keruagian ekonomi petani yang dirumuskan oleh Dinas Pertanian Kabupaten Gresik dapat diperkiran bahwa kerugian hasil dari komoditas padi di Desa Deliksumber sebesar Rp 32.340,75 /Kg , hasil tersebut dipengaruhi oleh luas tanaman yang terendam serta nilai produktivitas Desa Deliksumber. Sedangkan untuk jumlah total kerugian ekonomi petani mencapai Rp 155.235.600, dimana diperoleh dari nilai KH dikalikan dengan harga gabah per $\mathrm{Kg}$ di daerah bersangkutan. Kerugian-kerugian ini menjadi tanggung jawab petani, dimana sebagian besar petani memiliki dan mengakses lahan secara sewa atau bagi hasil dengan pemilik hasilnya. Dimana apabila terjadi gagal panen maka biaya pembelian bibit dan pupuk tambahan yang diperlukan harus ditanggung oleh petani.

Selain kerugian harga jual gabah yang menurun, kerugian yang dialami lainnya ialah kenaikan biaya produksi. Kenaikan biaya produksi ini terjadi karena rusaknya jalan usaha tani (JUT) desa akibat terendam banjir terus menerus setiap tahun serta sering dilalui oleh kendaraan yang tidak semestinya. Sebagian besar JUT berlubang dan bergelombang serta digenangi air banjir menjadi sulit untuk dilalui dan cukup berbahaya. Beberapa JUT juga masih berupa makadam belum ditingkatkan kualitasnya seperti JUT yang menuju Dusun Delikkulon.

Sehingga akses dari dan menuju lahan pertanian menjadi terbatas. Kerusakan ini meningkatkan harga biaya produksi untuk mengirimkan hasil dari sawah menuju rumah petani yang biasanya memakan biaya hanya Rp 5.000/Sak menjadi Rp 10.000/Sak - Rp 15.000/Sak. Peningkatan ini dapat meningkatkan biaya produksi dari petani itu sendiri dimana selain biaya pengiriman tersebut petani juga diharuskan mengeluarkan uang untuk biaya membeli bibit dan pupuk baru yang tidak gratis meskipun ketika banjir.

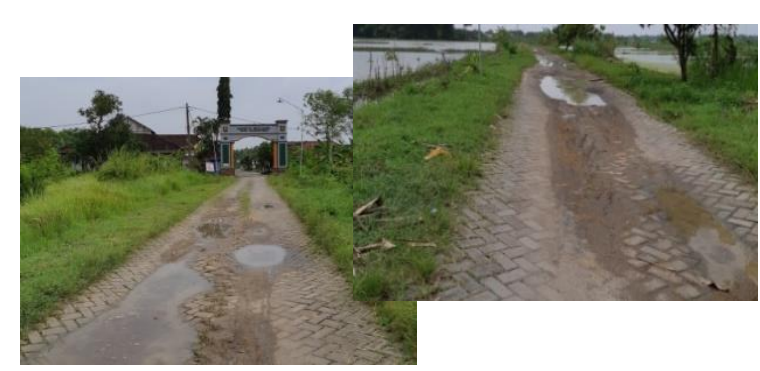




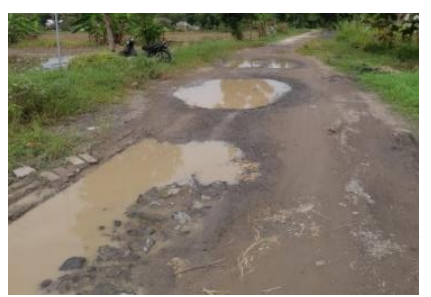

Gambar 2. Kondisi Jalan Usaha Tani Deliksumber

Kerugian yang dialami petani ditahun 2018 ini meski belum terekam datanya oleh BAPPEDA maupun Dinas Pertanian Kabupaten Gresik, dapat diketahui berdasarkan hasil survey primer bahwa banjir tahun ini frekuensi kejadiannya lebih banyak dari tahun sebelumnya yakni selama kurun waktu 5 - 19 Maret 2018 telah terjadi setidaknya 6 kali banjir kiriman dari Kali Lamong. Meskipun begitu, kerugian ekonomi bisa diperkirakan berkurang, karena banjir datang ketika masa panen telah dilakukan. Namun yang merugikan ialah harga biaya produksi untuk mengirimkan hasil dari sawah menuju rumah petani yang masih tinggi yakni Rp 10.000/Sak - Rp 20.000/Sak tergantung dari jarak lahan sawah ke rumah petani serta kondisi JUT menjadi lebih rusak dari tahun sebelumnya.

Selain itu, MT II harus tertunda hingga 2 minggu karena lahan sawah yang terendam banjir tidak kunjung surut. Meskipun ada beberapa petani yang sudah mulai menanam bibit padinya seperti yang dilakukan oleh Mbok Lan dari Dusun Sumber, beliau tetap mengeluhkan bahwa pertumbuhan padi yang telah ditanamnya sangat lambat dimana ukurannya tanamannya lebih pendek dari ukuran seharusnya, dikarenakan terlalu sering terendam air banjir serta pupuk yang diberikan tidak dapat bekerja dengan baik akibat terbawa oleh air banjir. Sedangkan upaya untuk menanam kembali bibit hanya dapat dilakukan apabila air banjir sudah surut dan dapat diprediksikan tidak datang lagi agar tidak mengalami kerugian kekurangan bibit dan pupuk untuk ditanam diperiode MT II. Merumuskan Usulan Upaya yang Harus dilakukan Berdasarkan Masyarakat

Adapun analisa ini dilakukan untuk mengetahui upaya adaptasi yang didapat diberikan oleh pemerintah sebagai usaha untuk meningkatkan ketahanan petani terhadap banjir. Berikut ini merupakan kode dan table analisa content analysis yang diterapkan terhadap usulan penanganan masalah berdasarkan masyarakat.

1) Kode Stakeholder Internal Wilayah Penelitian

Kode Stakeholder Desa Deliksumber, Kecamatan Benjeng Kode untuk menunjukkan stakeholder (instansi/ lembaga/ badan) di Desa Deliksumber

Tabel 1.

Kode Stakeholder Content Analysis

\begin{tabular}{|c|c|c|c|}
\hline Huruf & Angka & Warna & Stakeholder \\
\hline $\mathrm{Ga}$ & 1 & & Kantor Desa Deliksumber \\
\hline $\mathrm{Pa}$ & 1 & & Gabungan Kelompok Tani \\
\hline
\end{tabular}

Maka Kantor Desa dapat dikodekan dengan Ga.1

2) Kode Usulan Adaptasi

Kode untuk menunjukkan usulan arahan adaptasi yang disampaikan oleh stakeholder terkait

Tabel 2.

Kode Usulan Adaptasi

\begin{tabular}{|l|l|l|}
\hline Huruf & Angka & Usulan \\
\hline \multirow{2}{*}{$\mathrm{U}$} & 1 & Normaslisasi dan Tanggul Kali Lamong \\
\cline { 2 - 3 } & 2 & Mengaktifkan dapur umum dan bantuan sembako \\
\hline
\end{tabular}

Berdasarkan hasil analisa dapat di ketahui bahwa usulan yang diberikan oleh masyarakat ialah sebagai berikut:

a. Normaslisasi dan Tanggul Kali Lamong

Usulan adapatasi normalisasi tanggul kali lamong ini muncul dalam interview sebanyak 5 kali dimana masyarakat menekan pentingnya upaya normalisasi dan pembuatan tanggul Kali Lamong ini

“...kita itu bisanya cuma bisa mengusulkan tanggul tanggul normalisasi tapi ya buktine sampe sekarang ya ngga onok realisasi wes sering mba kita setiap tahun ada rapat di Balai besar bengawan solo itu nol hasilnya sampe sekrang.." - Bapak Totok, Sekertaris Desa Deliksumber, 2018

“...terus buat yang normalisasi atau tanggul Kali Lamong itu kan ya pasti itu mba semua desa yang kena banjir kiriman kali lamong itu pasti sama ..." - Bapak Muzamil, Ketua Poktan, 2018

“...yawes itu aja mba tanggul kali lamong itu segera dilaksanakan kemarin katanya sudah diusulkan itu sampai sekarang belum ada tindak lanjut y awes paling efektif itu mba kalau bisa terealisasi. Meskipun ngga ditanggul yaa dinormalisasi aja lah, semua pasti yang getol itu..." - Bapak Sokran, Kepala Kelompok Tani Dusun Bulang, 2018

Adanya usulan normalisasi dan tanggul kali lamong ini merupakan upaya mitigasi utama yang perlu diupayakan dengan harapan bahwa apabila kondisi kali lamong normal maka sungai Kali Lamong diharapkan dapat menampung debit air dengan jumlah yang lebih besar sehingga frekuensi banjir dikabupaten Gresik juga akan berkurang begitu pula dengan tinggi redaman airnya tidak berlangsung lama dan dalam. Dengan begitu, usulan ini bertujuan untuk mencegah timbulnya peningkatan kerugian ekonomi masyarakat terhadap banjir untuk tahun kedepannya.

b. Memberikan hibah atau modal berupa bibit, pupuk, alat pertanian

Berdasarkan hasil In-depth interview yang telah dilakukan usulan bagi pemerintah untuk memberikan hibah atau modal bagi petani berupa bibit, pupuk dan alat-alat pendukung kegiatan pertanian seperti cangkul, arit, traktor, maupun mesin diesel. Hal ini terngungkapkan sebanyak 6 kali oleh masyarakat melihat ketika pasca banjir bantuan inilah yang paling dibutuhkan oleh masyarakat petani yakni modalnya untuk melanjutkan kegiatan pertanian.

“... ya bantuan bibit atau pupuk juga perlu alat tani kayak traktor itu mba disini Cuma Satu ..” - Bapak Sokran, Kepala Kelompok Tani Dusun Bulang, 2018

“..yo mba nek onok bencana bencana gitu enak $e$ dikasih bantuan pupuk bibit uang ya itu bisa sedikit banyak ngurangi beban..." - Bapak Muzamil, Ketua Poktan, 2018

“...kalau misalnya itu penghapusan bibit pupuk, nah masalahnya yang dibutuhkan bibit pupuk pas banjir..." - Bapak Totok, Sekertaris Desa Deliksumber, 2018 
“...setahu nya saya lo mba ya bantuan bibit pupuk itu ya jumlahnya itu ya kalau bisa ya disesuaikan sama permintaan itu kan ya mba biar ndak susah baginya.." Bapak Totok, Sekertaris Desa Deliksumber, 2018

Menurut pendapat masyarakat dan pihak sekretaris desa dapat dipahami bahwa bantuan yang dibutuhkan oleh masyarakat adalah bantuan hibah berupa bibit, pupuk, maupun alat pertanian yang sesuai dengan jumlah petani yang membutuhkan adanya agar dapat di bagi secara merata dan kerugian yang dihadapi masyarakat dapat berkurang dan bisa dijadikan modal untuk masa tanam selanjutnya.

c. Mengaktifkan dapur umum dan bantuan sembako

Pengaktifan kembali dapur umum dan bantuan sembako di Desa Deliksumber dianggap perlu dilakukan kembali oleh masyarakat. Hal ini dinyatakan dalam prose in-depth interview dengan frekuensi 5 kali muncul dari pendapat masyarakat mengapa mereka membutuhkan upaya ini untuk dilakukan oleh pmeerintah pasca bencana banjir.

“...tapi bantuan yang dikasih kan sebatas mie instan,nasi bungkus,..” -- Bapak Totok, Sekertaris Desa Deliksumber, 2018

“...mba kalau banjir aja ya dilihat aja, kalau dapat bantuan ya nasi bungkus, sembako itu aja mba..” Bapak Muzamil, Ketua Poktan, 2018

“...kalau bantuan ekonomi kita bantunya dari masyarakat yang terdampak saja dibantu kebutuhan sehari-harinya lah mba selama banjir itu kayak disediain dapur umum dikasih sembako.." - Bapak Sokran, Kepala Kelompok Tani Dusun Bulang, 2018

Mengaktfkan dapur umum dan pemeberian bantuan sembako merupakan salah satu hal dasar yang diperlukan pada saar banjir bagi petani yang terisolasi dirumah mereka masing-masing karena alat transportasi yang dimiliki tidak berfungsi untuk mencari bahan makanan saat banjir. Meskipun, sebenarnya kegiatan pemberian bantuan sembako sering dilakukan namun jumlah yang sedikit tidak mampu mencakup semua kebutuhan setiap anggota masyarakat petani yang terdampak sehingga terkadang ada beberapa rumah tangga yang harus rela untuk tidak mendapatkan bantuan tersebut. Karena itu, usulan ini berfungsi untuk membantu masyarakat memenuhi kebutuhan pangan sehari harinya.

\section{KESIMPULAN}

Pada hasil penelitian yang dilakukan petani di Desa Deliksumber mengalami kerusakan bibit dan tanaman namun tidak untuk kerusakan lahan pertanian karena setelah air banjir surut lahan pertanian dapat berfungsi kembali. Menurut data Dinas Pertanian Kabupapten Gresik pada tahun 2017, Desa Deliksumber mengalami kerusakan bibit dan tanaman dengan jenis Ciherang seluas $107 \mathrm{Ha}$, Harga panen/Kg dari gabah padi yang dijual menurun hingga $21 \%$. Selain kerugian harga jual gabah yang menurun, kerugian yang dialami lainnya ialah kenaikan biaya produksi. Kenaikan biaya produksi ini terjadi karena rusaknya jalan usaha tani (JUT). Pada tahun 2017, secara keseluruhan berdasarkan perhitungan dapat diperkiran bahwa kerugian hasil dari komoditas padi di Desa Deliksumber sebesar Rp $32.340,75 / \mathrm{Kg}$, hasil tersebut dipengaruhi oleh luas tanaman yang terendam serta nilai produktivitas. Sedangkan untuk jumlah total kerugian ekonomi petani atau kerugian kegiatan pertanian mencapai Rp 155.235.600 bagi Desa Deliksumber.

Berdasarkan hasil analisa disimpulkan terdapat tiga jenis upaya yang dapat dilakukan oleh pemerintah untuk meningkatkan resiliensi masyarakat ketika banjir berdasarkan usulan dari masyarakat deliksumber diantara lainnya adalah memberikan bantuan modal petanian berupa bibit, pupuk, maupun alat pertanian yangmana bantuan ini sangat membantu untuk petani-petani yang tidak memiliki modal untuk melanjutkan kegiatan pertanian pada masa tanam selanjutnya. Selain itu juga diperlukan tindakan normalisasi dan pembuatan tanggul kali lamong yang merupakan agenda tahunan yang tidak terlaksankan pula setiap tahunnya msekipun selalu diusulkan padahal dampak positif dari kegiatan ini begitu berpengaruh terhadap kegiatan ekonomi masyarakat diseitarnya. Adapun bagi masyarakat tersedianya dapur umum dan bantuan sembako merupakan salah satu bentuk upaya yang bisa membantu masyarakat untuk kmbali pulih lagi dari kerugian bencana banjir.

\section{DAFTAR PUSTAKA}

[1] Wijaya. (2015). Penentuan Jalur Evakuasi Banjir di Kecamatan Cerme Gresik. Paper and Presentation of Civil Engineering and Planning, ITS.

[2] UNISDR. (2009, Januari 23). Terminology. Dipetik Februari 15, 2017, dari UNISDR (Uniter Nations Office for Disaster Risk Reduction): http://www.unisdr.org/we/inform/terminology

[3] UNISDR. (2009, Januari 20). Terminology. Diambil kembali dari https://www.unisdr.org/: https://www.unisdr.org/we/inform/terminology

[4] Rose, A. ( 2009 ). ECONOMIC RESILIENCE TO DISASTERS California : CARRI Research Report 8

[5] BPBD Kabupaten Gresik (2017). Data Kejadian Bencana Kabupaten Gresik 2014-2017

[6] Bakornas-PB. (2007). Pengenalan Karakteristik Bencana dan Upaya Mitigasinya di Indonesia Edisi II. Jakarta: Pelaksana Harian Badan Koordinasi Nasional Penanganan Bencana.

[7] BNPB. (2011). Peraturan Kepala Badan Nasional Penanggulangan Bencana Nomor 15 Tahun 2011 Tentang Pedoman Kajian Kebutuhan Pasca Bencana. Jakarta: BNPB.

[8] Perka BNPB. (2012). Peraturan Kepala Badan Nasional Penanggulangan Bencana Nomor 02 Tahun 2012 tentang Pedoman Umum Pengkajian Resiko Bencana. Jakarta: Badan Nasional Penaggulangan Bencana (BNPB).

[9] RTRW Kabupaten Gresik 2010-2030

[10] Harkunti P. Rahayu, d. (2009). Banjir dan Upaya Penanggulangannya. Bandung: PROMISE Indonesia, ADPC.

[11] Nurridwan, E. (2016). Strategi Dan Kelentingan Nafkah Rumahtangga Petani Di Daerah Rawan Bencana (Kasus Rumahtangga Petani D Desa Tunggilis, Kecamatan Kalipucang, Kabupaten Pangandaran, Provinsi Jawa Barat)

[12] Yulaelawati E. . Syihab U. (2008). Mencerdasi Bencana : Banjir, Tanah longsor, Tsunami, Gempa Bumi, Gunung Api, Kebakaran. Jakarta

[13] Rosyidie, A. ( 2013). Banjir: Fakta dan Dampaknya, Serta Pengaruh dari Perubahan Guna Lahan . Jurnal Perencanaan Wilayah dan Kota, $.241-249$

[14] Yunida, R., Kumalawati, R., \& Arisanty, D. (2017 ). Dampak Bencana Banjir Terhadap Kondisi Sosial Ekonomi Masyarakat Di Kecamatan Batu Benawa Kabupaten Hulu Sungai Tengah, Kalimantan Selatan . JPG (Jurnal Pendidikan Geografi), Volume 4 No 4 : $42-52$ 